\title{
Familial patent arterial duct
}

INSERM

\section{Source}

INSERM. (1999). Orphanet: an online rare disease and orphan drug data base. Familial patent arterial duct. ORPHA:466729

Familial patent arterial duct is a rare, genetic, non-syndromic, cong enital anomaly of the great arteries characterized by the presence of an isolated patent arterial duct (PDA) (i.e. failure of closure of ductus arteriosis after birth) in several members of the same family. Clinical presentation is similar to the sporadic form and may range from neonatal-onset tachypnea, diaphoresis and failure to thrive to adult-onset atrial arrhythmia, signs and symptoms of heart failure and cyanosis limited to the lower extremities. 